\title{
A child confirmed COVID-19 with only symptoms of conjunctivitis and eyelid dermatitis
}

\author{
Ping $\mathrm{Wu}^{1} \cdot$ Liang Liang ${ }^{1} \cdot$ ChunBao Chen ${ }^{2} \cdot$ ShengQiong Nie ${ }^{1}$ \\ Received: 3 April 2020 / Revised: 5 April 2020 / Accepted: 15 April 2020 / Published online: 24 April 2020 \\ (C) Springer-Verlag GmbH Germany, part of Springer Nature 2020
}

\section{Dear Editor,}

As we all know, the 2019 novel coronavirus disease (COVID-19) infected by SARS-CoV-2 are spreading worldwide. It was reported that there were different clinical features between pediatric and adult patients with COVID-19 [1]. Our previous study had shown that conjunctivitis symptoms were found in a minority of adult patients confirmed COVID-19, with positive results of viral nucleic acid in conjunctival swab samples [2]. Nevertheless, there are no reports in the medical literature at this time, to our knowledge, on children infected by SARS-CoV-2 with ocular abnormalities. Here we firstly report an infected boy characterized by conjunctivitis and eyelid dermatitis without any other symptom.

The child, 2 years and 10 months old, was detected and confirmed through community screening with positive result of SARS-Cov-2 nucleic acid in his nasopharyngeal swabs on February 17, 2020. He likely acquired SARS-CoV-2 infection from his household member because of his father and grandma diagnosed before. He was quarantined at a government designated hotel with his mother, for being asymptomatic initially. On day 7 of confinement, the child presented with conjunctivitis and eyelid dermatitis (Fig. 1), and was referred to our hospital subsequently. Admission tests reconfirmed the SARSCoV-2 infection by RT-PCR, meanwhile revealed myocardial damage and atypical change in lymphocyte count (Table 1), with normal chest CT. After treatment

Liang Liang

liangliang419519@ctgu.edu.cn

1 Department of Ophthalmology, Yichang Central People's Hospital, The first college of Clinical Medical Science, China Three Gorges University, Yichang 443003, People's Republic of China

2 Department of Pediatrics, Yichang Central People's Hospital, The first college of Clinical Medical Science, China Three Gorges University, Yichang 443003, People's Republic of China depending on the national protocol in China [3], conjunctivitis and eyelid dermatitis gradually disappeared 5 days later. From days 10 to 12 of admission, negative results of viral nucleic acid twice in $48 \mathrm{~h}$, with positive IgG but negative $\operatorname{IgM}$ of the virus in serum, indicated that the virus had been cleared [4]. The child left hospital on March 7, 2020, with no respiratory and other systemic symptoms until now.

Our child was found muscle enzyme elevation unintentionally; meanwhile, the trend of recovery was not clear when leaving hospital (Table 1). It indicated that we should closely track the blood indexes of child patients as soon as earlier to know the condition of myocardium and whole system after diagnosed even though without any clinical manifestation.

Lymphocyte count usually decreased in the early stage of most adult cases [5], while that of this child was slightly higher than normal in admission tests. To some extent, it was related to that the count and proportion of lymphocytes in children under 5 years old are higher than those in adults in the general population. Therefore, the significance of this test for early diagnosis of COVID-19 should be combined with age and need to be confirmed by large sample data.

Studies had shown that ACE2 is a receptor of SARSCoV-2 to invasion [6]. ACE2 is expressed not only in human type II alveolar epithelial cells, but also in cornea and conjunctiva [7], suggesting that ocular surface tissue may also be a potential target tissue infected by SARS-CoV-2. Our previous report had shown that conjunctivitis symptoms were found in a small number of adult patients confirmed COVID-19 [2]. However, so far, there has been no report on infected children with eye symptoms. This case showed a child involved conjunctivitis and eyelid dermatitis on day 7 of COVID-19 confirmed. It may be caused by virus infection, or by secondary bacterial infection with poor body resistance after systemic virus infection. 
Fig. 1 a and b Day 1 of conjunctival congestion and eyelid redness and swelling in the left eye admission. The pictures showed
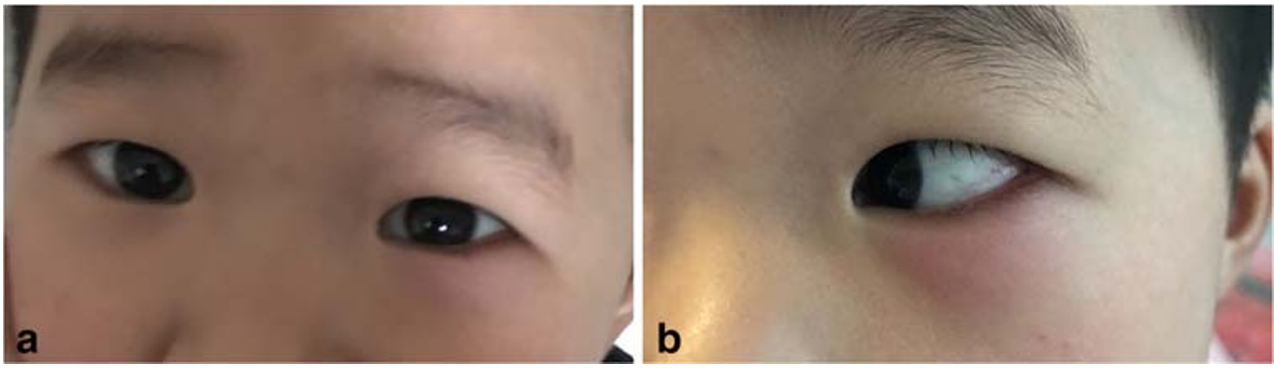

\begin{tabular}{llll}
\hline & 1 st day & 11th day & Reference range \\
\hline White blood cell count, $* 10^{9} / \mathrm{L}$ & 9.57 & 5.02 & $3.5-9.5$ \\
Lymphocyte count, $* 10^{9} / \mathrm{L}$ & 4.48 & 3.20 & $1.1-3.2$ \\
Neutrophil count, ${ }^{9} 10^{9} / \mathrm{L}$ & 4.29 & 1.22 & $1.8-6.3$ \\
Platelet count, ${ }^{9} / \mathrm{L}$ & 289 & 298 & $125-350$ \\
Procalcitonin $(\mathrm{PCT}), \mathrm{ng} / \mathrm{mL}$ & $<0.05$ & - & $0-0.05$ \\
C- reactive protein $(\mathrm{CRP}), \mathrm{mg} / \mathrm{L}$ & 6.5 & 0.5 & $0-10$ \\
Troponin I (CTnI), $\mu \mathrm{g} / \mathrm{L}$ & $<0.01$ & $<0.01$ & $0-0.01$ \\
Myoglobin $(\mathrm{MYO}), \mu \mathrm{g} / \mathrm{L}$ & 17 & 60 & $10-46$ \\
Creatine kinase $(\mathrm{CK}), \mathrm{IU} / \mathrm{L}$ & 295 & - & $50-310$ \\
Creatine kinase isoenzyme-MB (CKMB), $\mu \mathrm{g} / \mathrm{L}$ & 6.38 & 6.77 & $0-5.1$ \\
Lactate dehydrogenase (LDH), IU/L & 329 & - & $120-250$ \\
Alanine aminotransferase (ALT), U/L & 24 & 20 & $9-50$ \\
Aspartate minotransferase (AST), U/L & 35 & 30 & $15-40$ \\
Urea, mmol/L & 5.37 & - & $3.1-8.0$ \\
Creatinine, umol/L & 27.1 & - & $57-97$ \\
\hline
\end{tabular}

Table 1 Partial results of blood tests after admission
Therefore, we suggest that doctors should not forget to conduct COVID-19 screening when children come to hospital for ocular abnormalities during this epidemic period. Except for the specific detection of viral nucleic acid, the results of other laboratory tests of SARS-COV-2 infection in children had no obvious specificity.

Funding information This study was supported by grants 81770920 (Dr Liang) from the National Natural Science Foundation of China.

\section{Compliance with ethical standards}

Conflict of interest The authors declare that they have no conflict of interest.

Consent for publication We thank the patient and his parents for granting permission to publish this information.

\section{References}

1. Shen K, Yang Y, Wang T et al (2020) Diagnosis, treatment, and prevention of 2019 novel coronavirus infection in children: experts' consensus statement. World J Pediatr. https://doi.org/10.1007/ s12519-020-00343-7
2. Wu P, Duan F, Luo C, Liu Q, Qu X, Liang L, Wu K (2020) Characteristics of ocular findings of patients with coronavirus disease 2019 (COVID-19) in Hubei Province, China. JAMA Ophthalmol. https://doi.org/10.1001/jamaophthalmol.2020.1291

3. General Office of National Health Committee, Office of State Administration of traditional Chinese Medicine (2020) Notice on the issuance of a programme for the diagnosis and treatment of novel coronavirus (2019-nCoV) infected pneumonia (trial sixth edition) (In Chinese). http://www.nhc.gov.cn/yzygj/s7653p/202002/ 8334a8326dd94d329df351d7da8aefc2.shtml. Accessed March 12, 2020

4. Li Z, Yi Y, Luo X et al (2020) Development and clinical application of a rapid IgM-IgG combined antibody test for SARS-CoV-2 infection diagnosis. J Med Virol. https://doi.org/10.1002/jmv.25727

5. Wang D, Hu B, Hu C et al (2020) Clinical characteristics of 138 hospitalized patients with 2019 novel coronavirus-infected pneumonia in Wuhan, China. JAMA. https://doi.org/10.1001/jama.2020.1585

6. Wan Y, Shang J, Graham R, Baric RS, Li F (2020) Receptor recognition by novel coronavirus from Wuhan: an analysis based on decade-long structural studies of SARS. J Virol. https://doi.org/10. 1128/JVI.00127-20

7. Zou X, Chen K, Zou J, Han P, Hao J, Han Z (2020) Single-cell RNAseq data analysis on the receptor ACE2 expression reveals the potential risk of different human organs vulnerable to $2019-\mathrm{nCoV}$ infection. Front Med. https://doi.org/10.1007/s11684-020-0754-0

Publisher's note Springer Nature remains neutral with regard to jurisdictional claims in published maps and institutional affiliations. 